\title{
Bahagiakah Siswa Belajar Dimasa Pandemi?
}

\author{
Cahaya Makbul $^{1}$, Mulkismawati ${ }^{2}$, Mangisi Erlinda ${ }^{3}$ \\ 1,2,3 Fakultas Psikologi, Universitas Islam Negeri Sultan Syarif Kasim Riau \\ cahaya.aya65@gmail.com
}

\begin{abstract}
Abstrak
Penelitian ini bertujuan untuk mengetahui kondisi bahagia atau tidaknya siswa dalam mengikuti pembelajaran daring selama masa pandemic dan kendala yang dirasakan siswa selama mengikuti sistem pembelajaran daring. Kajian ini merupakan survey terhadap 131 pelajar kelas VII (tujuh) dengan menggunakan pertanyaan terbuka tentang bahagiakah siswa belajar dimasa pandemic dengan menggunakan google form. Dari hasil penelitian diketahui bahwa siswa banyak merasa tidak bahagia $90.06 \%$ dan hanya 9.94\% siswa yang merasa bahagia selama pembelajaran daring dimasa pandemic dan siswa mengalami kendala dalam pemahaman materi pembelajaran karena tidak ada penjelasan dari guru dengan persentase $47.3 \%$ kemudian $22.1 \%$ siswa mengalami kendala kuota, 7.6\% tidak ada HP, $17.6 \%$ terlalu banyak tugas dan 5.5\% tidak ada buku paket dirumah.
\end{abstract}

Kata kunci: Covid-19; kendala; kebahagiaan; pembelajaran daring

\begin{abstract}
This study aims to determine whether students are happy or unhappy in participating in online learning during the pandemic and the obstacles that students feel during the online learning system. This study is a survey of 131 grade VII (seven) students using open-ended questions about whether students learn during a pandemic using google form. Results is that $90.06 \%$ of students feel unhappy and only 9.94\% of students feel happy during online learning during the pandemic and students experience problems in understanding the learning material because there is no explanation from the teacher with a percentage of $47.3 \%$ then $22.1 \%$ of students experience quota constraints, $7.6 \%$ do not have cell phones, $17.6 \%$ have too many tasks and $5.5 \%$ do not have textbooks at home.
\end{abstract}

Key word: Covid-19, obstacles, happiness, online learning

\section{Pendahuluan}

Pada 30 Desember 2019, Wuhan Municipal Health Committee mengeluarkan pernyataan "urgent notice on the treatment of pneumonia of unknown cause" hingga membuat keresahan secara global dengan adanya corona virus disease (Covid-19) yang diduga berasal dari pasar ikan dan hewa yang ada di Wuhan hingga kasus suspek terus meningkat. Covid-19 telah menyebar diberbagai Negara yang kini telah menjadi pandemi global, bahkan di Indonesia. 
Coronavi-rus disease 2019 (COVID-19) merupakan salah satu penyakit infeksi dikarenakan oleh SARS-CoV-2, yang mempunyai bentuk dan perilaku yang mirip dengan virus SARS. Sebelumnya virus corona manusia (Human coronaviruses (HCoVs) dianggap virus yang kurang berbahaya karena penyebab flu biasa. Virus ini sudah pernah menyebabkan endemic s dengan morbiditas dan mortalitas cukup tinggi yaitu severe acute re-spiratory syndrome (SARS-CoV) dan middle east respiratory syndrome (MERS-CoV) pada saat beberapa tahun yang lalu. Jumlah akumulatif kasus MERS CoV dan SARS sekitar 10.000 yang terdiri dari 1000-an kasus MERS dan 8000-an kasus SARS. Rerata mortalitas akibat SARS sekitar 10\% sedangkan MERS lebih tinggi yaitu sekitar 40\% (Isbaniah \& Susanto, 2020). Virus covid-19 menyebabkan infeksi saluran pernapasan. Penegakan diagnosis dapat dilihat pada gejala umum berupa demam, batuk dan sulit bernapas. Pengambilan swab pada tenggorokan dan saluran pernapasan menjadi tolakukur penegakan diagnosis coronavirus disease. (Yuliana, 2020).

Infeksi COVID-19 yang disebabkan virus corona baru merupakan suatu pandemik baru dengan penyebaran antar manusia yang sangat cepat. Derajat penyakit dapat bervariasidari infeksi saluran napas atas hingga ARDS. Diagnosis ditegakkan dengan RTPCR, hingga saat ini belum ada terapi antivirus khusus dan belum ditemukan vaksin untuk COVID-19 (Diah et al., 2020).

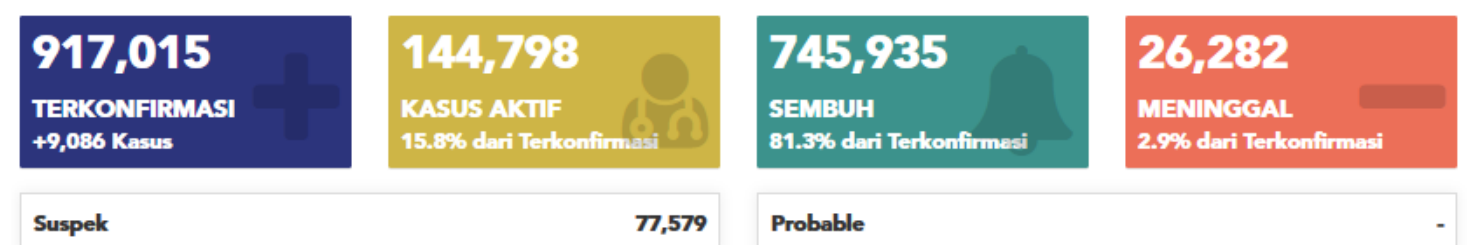

Gambar 1. Data Kasus Covid-19 di Indonesia hingga 18 Januari 2021(Sumber:https://covid19.go.id/petasebaran-covid19

Pada saat awal bulan Maret 2020 kasus pertama ditemukan di Indonesia yang memberikan dampak kepada berbagai line kehidupan warga Indonesia. Bukan hanya persoalan kesehatan tetapi juga berdampak pada ekonomi bahkan Pendidikan di Indonesia. Dengan adanya Covid-19 sistem Pendidikan di Indonesia pun berubah, sesuai keputusan pemerintah melalui Kementerian Pendidikan dan Kebudayaan, pebelajaran di berbagai jenjang pendidikan berubah menjadi system Daring (Dalam Jaringan) atau pembelajaran jarak jauh dengan menggunakan berbagai aplikasi yang dapat menghubungan guru dan siswa dari berbagai jarak untuk tetap belajar meski hanya dirumah.

Sistem pembelajaran daring yang dilaksankan selama pandemic covid-19, bahkan menimbulkan berbagai kendala yang dialami peserta didik dan para pengajar, dari mulai persoalan jaringan, kuota paket data, perangkat HP atau laptop yang tidak dimilki semua siswa, pemahana penggunaan aplikasi baik guru maupun siswa, sulitnya orang tua dalam pendampingan siswa selama belajar dirumah, terlebih lagi bagi keluarga yang berdampak secara ekonomi atau keluarga yang memang berasal dari ekonomi rendah menyebabkan sulitnya memenuhi biaya-biaya yang terkait pemenuhan kebutuhan anak selama belajar 
dirumah (Muhammad et al., 2020; Hutauruk \& Sidabutar, 2020; Taradisa, Nidia., Jarmita, Nida., 2020).

Dalam proses pembelajaran selama ini dilaksanakan secara tata muka didalam kelas dan tentunya peserta didik dan para pengajar harusnya merasakan kebahagian dalam proses belajar mengajar namun selama pandemic terjadi proses pembelajaran berubah menjadi sistem daring Sehingga perlu diketahui lebih lanjut bagaimana kebahagiaan siswa selama pembelajaran daring di masa pandemic dan apa kendala yang dihadapi selama proses pembelajaran daring.

Dalam merumuskan pengertian kebahagiaan tidaklah mudah karena memaknai kebahagiaan tentunya relatif berbeda bagi setiap individu, karena kebahagiaan dirasakan oleh masing-masing individu sehingga memungkinkan memiliki berbagai perbedaan dalam mendefinisikan kebahagiaan. Dalam konsep teoritis yang mengarah dan menjelaskan tentang kebahagiaan dalam perspeksti teori psikologi barat yaitu psychological well-being (Ryff, 1989).

Menurut Ryff (Ryff, 1989), psychological well-being dapat menggambarkan kesejahteraan psikologis sesuai kriteria fungsi psikologi positif (positive psychological functioning). Dalam hal aplikasi PWB pada kehidupan sehari-hari, terdapat batasanbatasan bahwa kesejahteraan psikologis tidak hanya mengenai pencapaian kebahagian akan tetapi sebagai tujuan yang mengarah pada kesempurnaan dan kebaikan. PWB merujuk pada bagaimana individu mampu menngembangkan potensi diri secara optimal, baik secara fisik, emosional ataupun psikologis (Ryff \& Keyes, 1995). Pengertiam ini sesuai yang dikatakan oleh Alston dan Dudley (dalam Hurlock, 2004) menyatakan bahwa kebahagiaan merupakan kemampuan seseorang untuk menikmati pengalamanpengalamannya, yang disertai tingkat kegembiraan

Ryff (Ryff \& Keyes, 1995) menjelaskan psychologycal well-being dalam enam konsep, yaitu penerimaan diri adalah sikap positif terhadap diri sendiri dan masa lalu individu yang bersangkutan. Menggambarkan evaluasi diri yang positif, kemampuan mengakui aspek diri sendiri, dan kemampuan menerima positif dan negatif kemampuan seseorang. Hubungan yang positif dengan orang lain ini berkaitan dengan kemampuan menjalin hubungan antar pribadi yang hangat dan saling mempercayai. Menggambarkan orang yang terkatualisasi dirinya mempunyai perasa-an empati dan kasih sayang. Dimensi otonomi merupakan kemampuan untuk menentukan nasib sendiri, mandiri dan mengatur perilakunya sendiri. Dimensi ini meliputi independen dan determinan diri, kemampuan individu mehan tekanan sosial, dan kemampuan mengatur pelakunya dari dalam. Dimensi penguasaan lingkungan meliputi rasa penguasaan dan kompetensi serta kemampuan memilih situasi dan lingkungan yang kondu-sif. Menekankan perlunya keterlibatan dan dalam aktivitas di lingkungan, kemampuan untuk memanipulasi dan mengendalikan lingkungan yang rumit. Dimensi ini meliputi kesadaran akan tujuan dan makna hidup, serta arah dan keinginan dalam kehidupan. Pertumbuhan pribadi Adalah kegiatan dalam mengeksplorasi potensi diri untuk tumbuh dan berkembang sebagai individu dengan 
efektif berkaitan dengan kapasitas dalam mengembangkan kemampuan, serta melakukan perubahan setiap saat dalam pengetahuan diri.

(Diener, 2000) didefinisikan sebagai evaluasi kognitif dan afektif terhadap kehidupan seseorang. Adapun hasil evaluasi kognitif orang yang bahagia adalah adanya kepuasan hidup yang tinggi, sedangkan evaluasi afektifnya adalah banyaknya afeksi positif dan sedikitnya afeksi negatif yang dirasakan (Diener et al., 1999). Faktor-faktor yang mempengaruhi psychological well-being menurut Ryff (Galuh \& Utami, 2009) adalah :

a. Faktor Demografis

Faktor demografis yang mempengaruhi kese-jahteraan psikologis (psychological well-being) yaitu usia, jenis kelamin, status sosial ekonomi, dan budaya.

b. Dukungan Sosial

Merupakan rasa nyaman, perhatian, penghormatann ataupun pertolongan yang diperoleh dari berbagai sumber seperti keluarga, teman, tenaga medis ataupun pemerintah.

c. Evaluasi terhadap Pengalaman Hidup

Dalam pengalaman hidup berkaitan dengan berbagai line kehidupan selama periode kehidupan. Evaluasi terhadap pengalaman hidup mempunyai pengaruh penting dalam psychological well-being.

Pengalaman hidup mencakup berbagai bidang kehidupan dalam berbagai periode kehidupan. Evaluasi individu terhadap pengalaman hidupnya memiliki pengaruh yang penting terhadap kesejahteraan psikologis.

d. Locus of Control (LOC)

Locus of Control merupakan sebagai suatu ukuran harapan umum seseorang mengenai pengenda-lian (kontrol) terhadap penguatan (reinforcement) yang mengikuti perilaku tertentu, dapat memberikan peramalan terhadap psychological well-being

\section{Metode Penelitian}

Penelitian ini adalah survey terhadap 131 pelajar di SMP 45 Pekanbaru kelas VII (tujuh). Data dikumpulkan dengan metode pertanyaan terbuka yang diperoleh dengan mengunakan google from tentang kondisi yang dialami siswa/i selama menjalani metode pembelajaran daring selama pandemic dengan pertanyaan. Data dalam penelitian ini diperoleh dengan menggunakan pertanyaan terbuka yang memungkinkan subjek memberikan jawaban yang bervariatif karena pertanyaan tersebut tidak memiliki pilihan jawaban yang pasti atau sama. Hal ini mengacu pada pendekatan yang dikembangkan didalam buku (Kim et al., 2006) yang dianalisis dengan dengan content analysis dan frequrncy analysis dengan tahapan yaitu open coding, axial coding dan selective coding (Fathurcohman dkk, 2017). Selanjutnya tema-tema yang didapat dari analisis kontens dilakukan analisis lanjutan menggunakan SPSS untuk medeskripsikan secara terperinci. 
Psikobuletin: Buletin Ilmiah Psikologi

Vol. 2, No. 2, Mei, 2021 (91-103)

e-ISSN : $2720-8958$

DOI : 10.24014/pib.v2i2.12326

\section{Hasil Penelitian}

Data kajian ini diperoleh dari 131 orang responden yang merupakan siswa SMP Negeri 45 Pekanbaru yang tergambar dari gambar berikut ini :

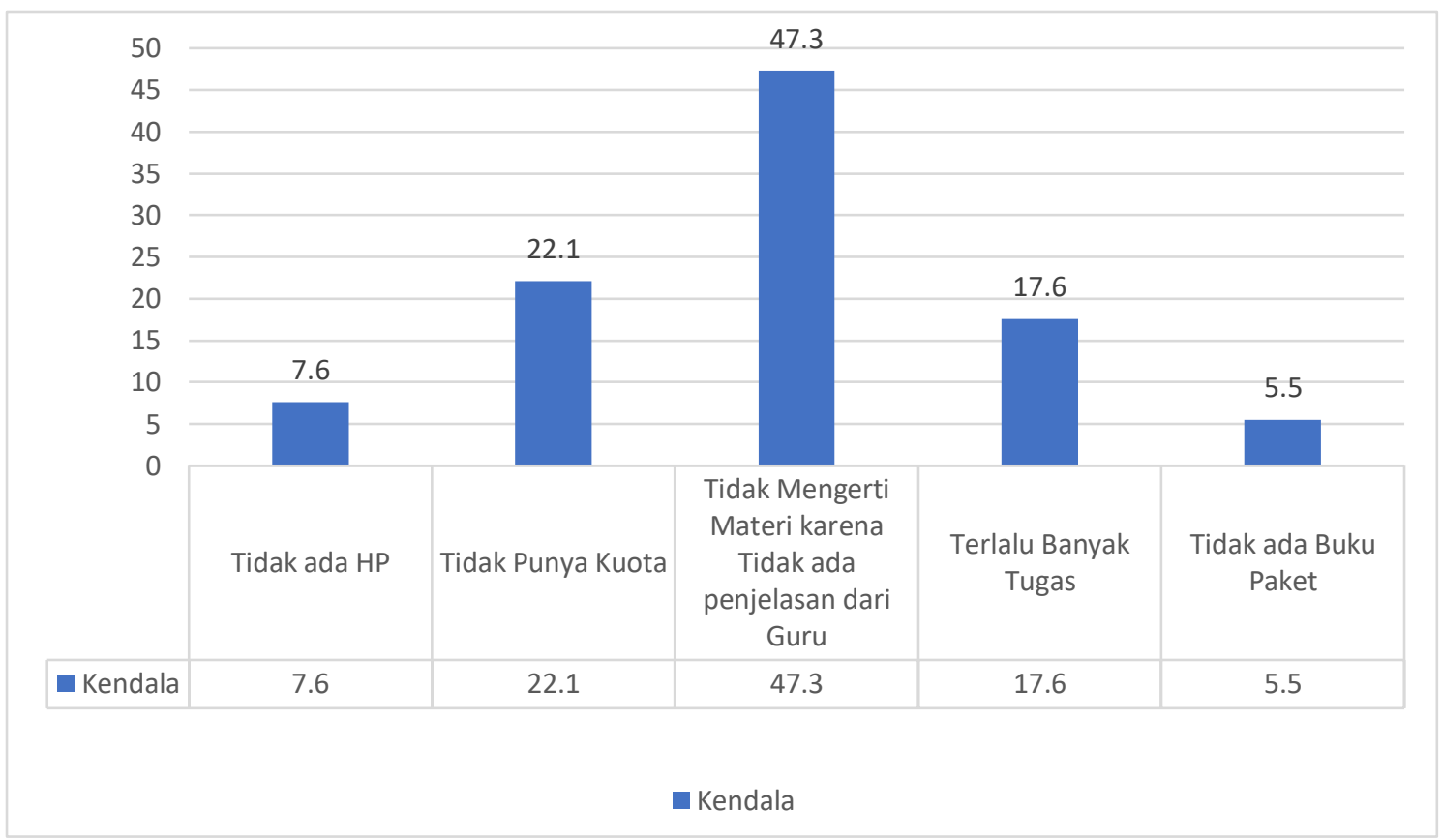

Gambar 2. Kendala yang dialami siswa dalam pembelajaran daring

Dari gambar 2. Diketahui bahwa siswa banyak mengalami kendala dalam pemahaman materi pembelajaran karena tidak ada penjelasan dari guru dengan persentase $47.3 \%$ kemudian $22.1 \%$ siswa mengalami kendala kuota, $7.6 \%$ tidak ada HP, $17.6 \%$ terlalu banyak tugas dan $5.5 \%$ tidak ada buku paket dirumah.

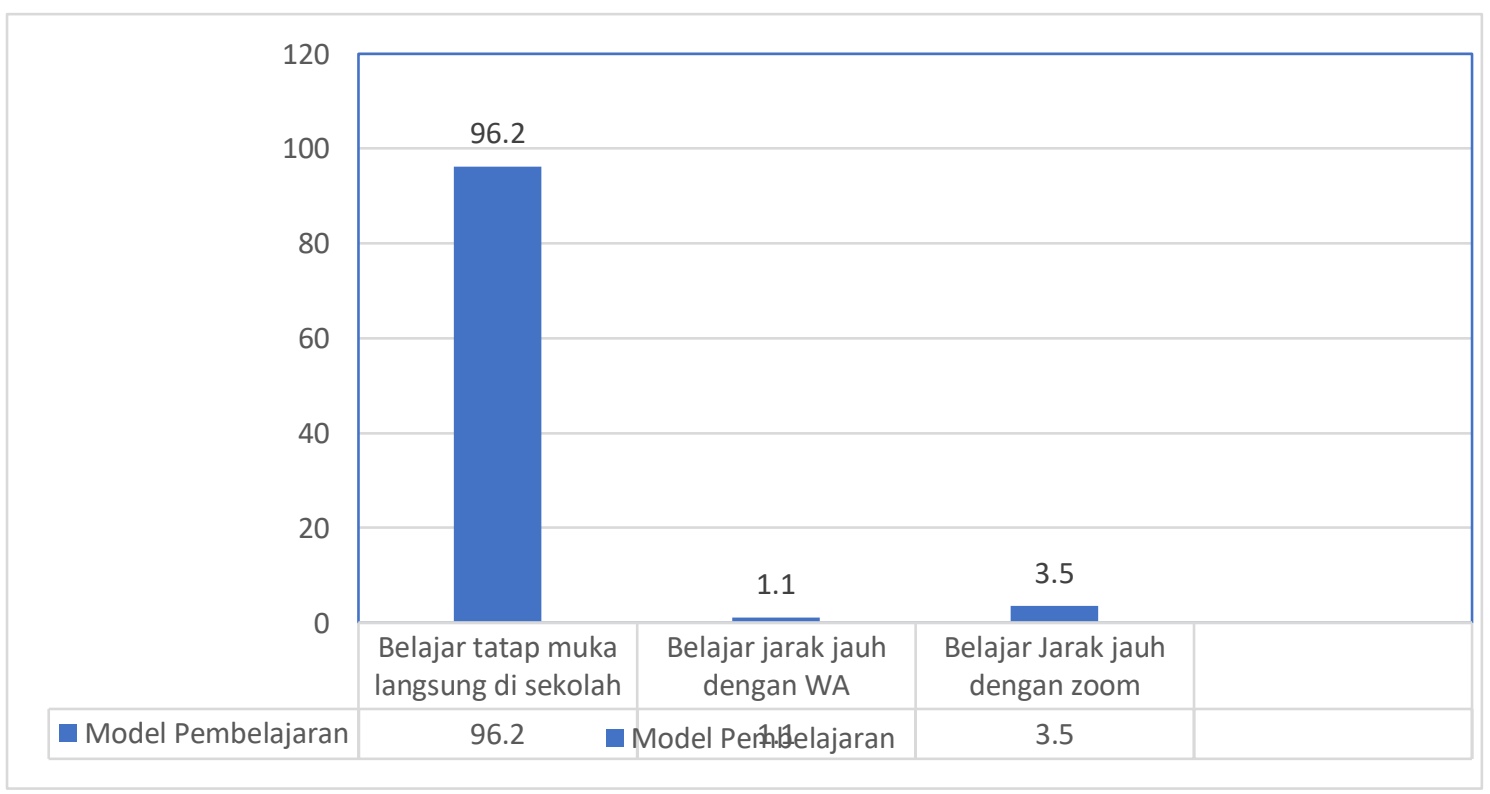

Gambar 3. Model pembelajaran 
Pada gambar 3. Diketahui bahwa model pembelajaran yang paling banyak disukai siswa adalah belajar tatap muka langsung di sekolah dengan persentase $96.2 \%$, dan selebihnya dengan system daring $3.5 \%$ daring dengan aplikasi zoom dan $1.1 \%$ daring dengan aplikasi WA.

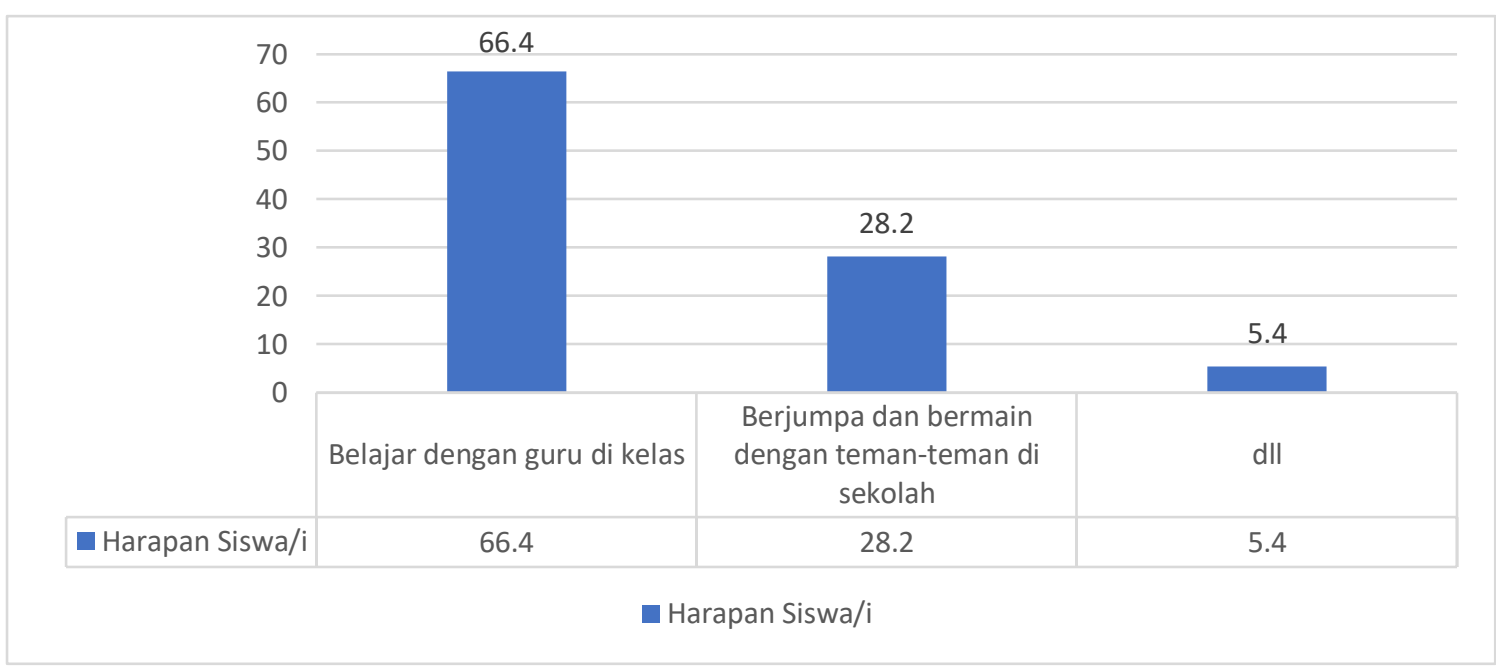

Gambar 4. Hal yang diinginkan pada kegiatan belajar

Berdasarkan gambar 4, diketahui bahwa hal yang paling banyak diinginkan atau dirindukan siswa dalam kegiataan belajar adalah belajar dengan guru di kelas dengan persentase $66.4 \%$, berjumpa dan bermain dengan teman-teman $28,2 \%$ dan berbagai hal di sekolah $5.4 \%$.

Tabel 1

Analisis Crosstabs

\begin{tabular}{lllllll}
\hline Variabel & Valid & \multicolumn{3}{c}{ Missing } & \multicolumn{2}{c}{ Total } \\
\cline { 2 - 7 } & $\begin{array}{l}\text { Jumlah } \\
(\mathbf{n})\end{array}$ & Persentase & $\begin{array}{l}\text { Jumlah } \\
(\mathbf{n})\end{array}$ & Persentase & $\begin{array}{l}\text { Jumlah } \\
(\mathbf{n})\end{array}$ & Persentase \\
\hline $\begin{array}{l}\text { Reason*Psychological } \\
\text { well-being*Jenis } \\
\text { kelamin }\end{array}$ & 131 & $100 \%$ & 0 & $0 \%$ & 131 & $100 \%$ \\
\hline
\end{tabular}

Berdasarkan hasil analisis crosstabs diketahui bahwa gambaran kebahagiaan siswa berdasarkan jenis kelamin dan alasan yang membuat siswa merasa bahagia dan tidak bahagia. Jika dilakukan persentase maka menemukan gambaran data seperti gambar 5,6 dan 7.

Berdasarkan gambar 5. Diketahui bahwa selama mengikuti proses pembelajaran daring selama masa pandemi siswa merasa tidak bahagia pada laki-laki sebanyak $40.45 \%$ dan siswa tidak bahagia perempuan sebanyak $49.62 \%$ sementara siswa perempuan yang merasa bahagia hanya sebanyak $6.87 \%$ dan siswa yang merasa bahagia pada laki-laki hanya $3.05 \%$. 
Psikobuletin: Buletin Ilmiah Psikologi

Vol. 2, No. 2, Mei, 2021 (91-103)

e-ISSN : $2720-8958$

DOI : 10.24014/pib.v2i2.12326

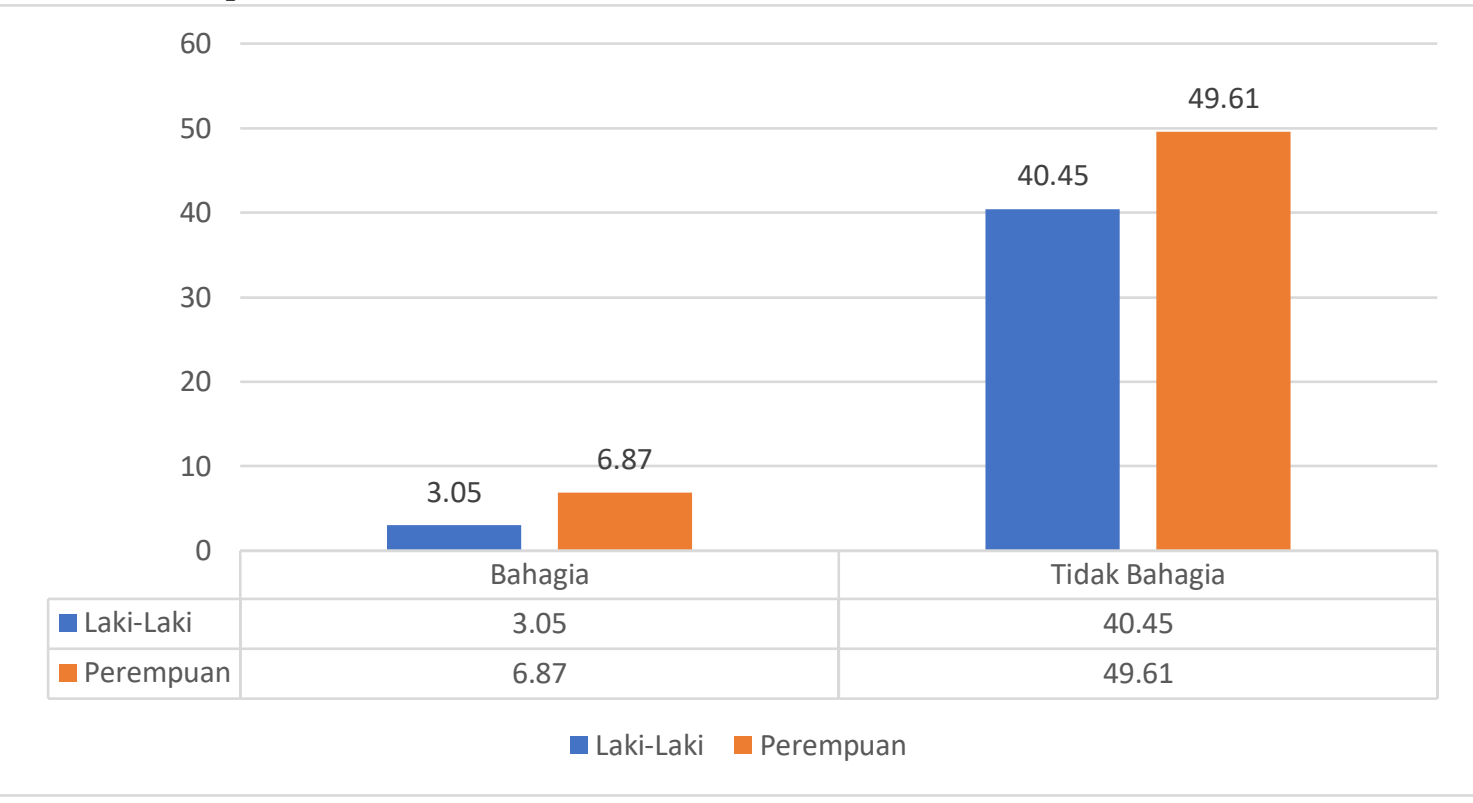

Gambar 5. Gambaran Kebahagian Siswa/siswi

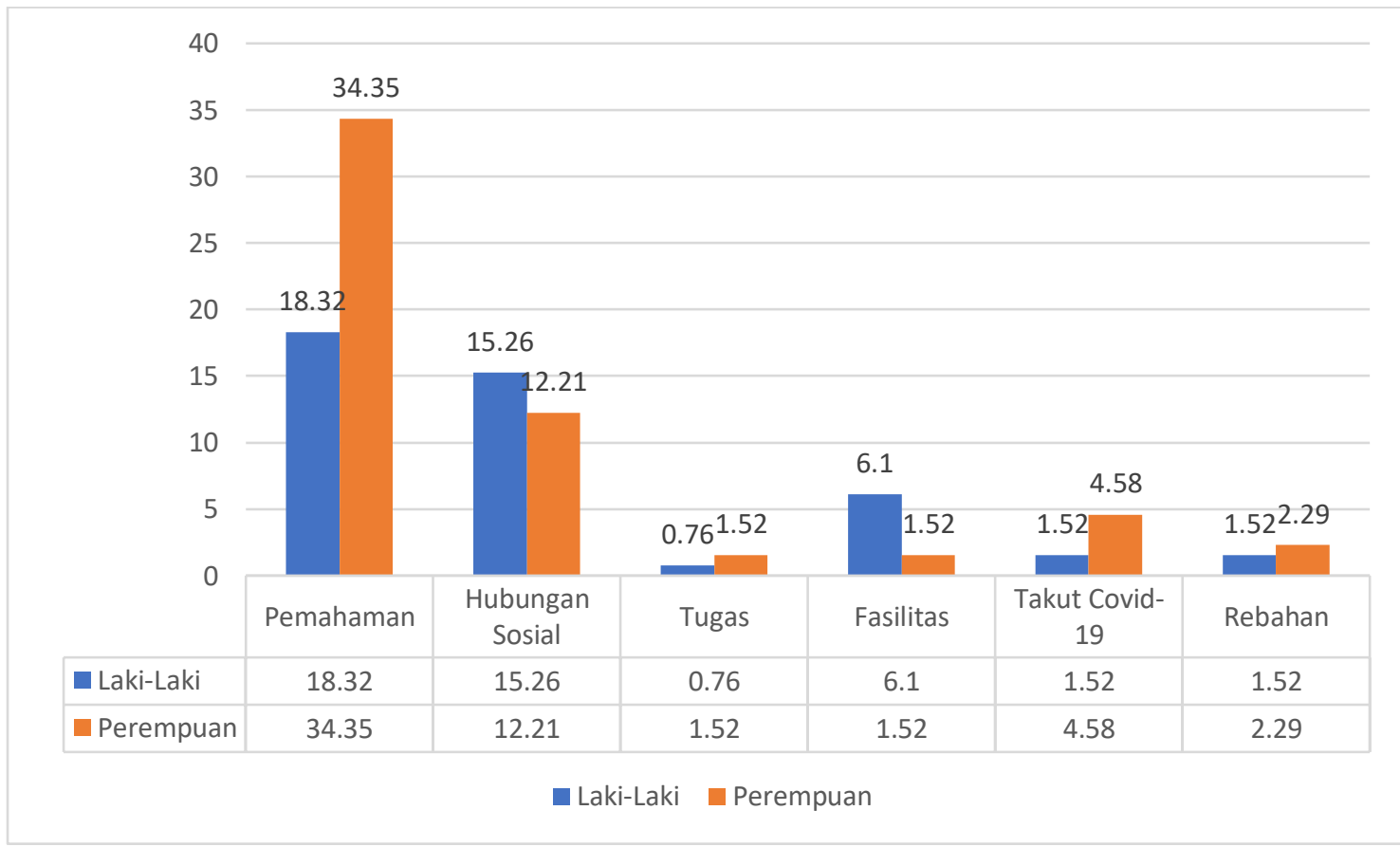

Gambar 6. Gambaran alasan kebahagiaan ditinjau berdasarkan jenis kelamin

Berdasarkan gambar 6. Diketahui bahwa alasan yang membuat siswa merasa bahagia atau tidak bahagia selama mengikuti pembelajaran daring selama pandemi jika ditinjau berdasarkan jenis kelamin berkaitan dengan pemahaman sebesar $18.32 \%$ pada laki-laki dan $34.35 \%$ pada perempuan, hubungan sosial sebesar $15.26 \%$ pada laki-laki dan $12.21 \%$ pada perempuan, tugas sekolah $0.76 \%$ pada laki-laki dan $1.52 \%$ pada perempuan, Fasilitas $6.1 \%$ pada laki-laki dan $1.52 \%$ pada perempuan, Takut tertular covid-19 $1.52 \%$ 
pada laki-laki dan $4.58 \%$ pada perempuan dan rebahan $1.52 \%$ pada laki-laki dan $2.29 \%$ pada perempuan.

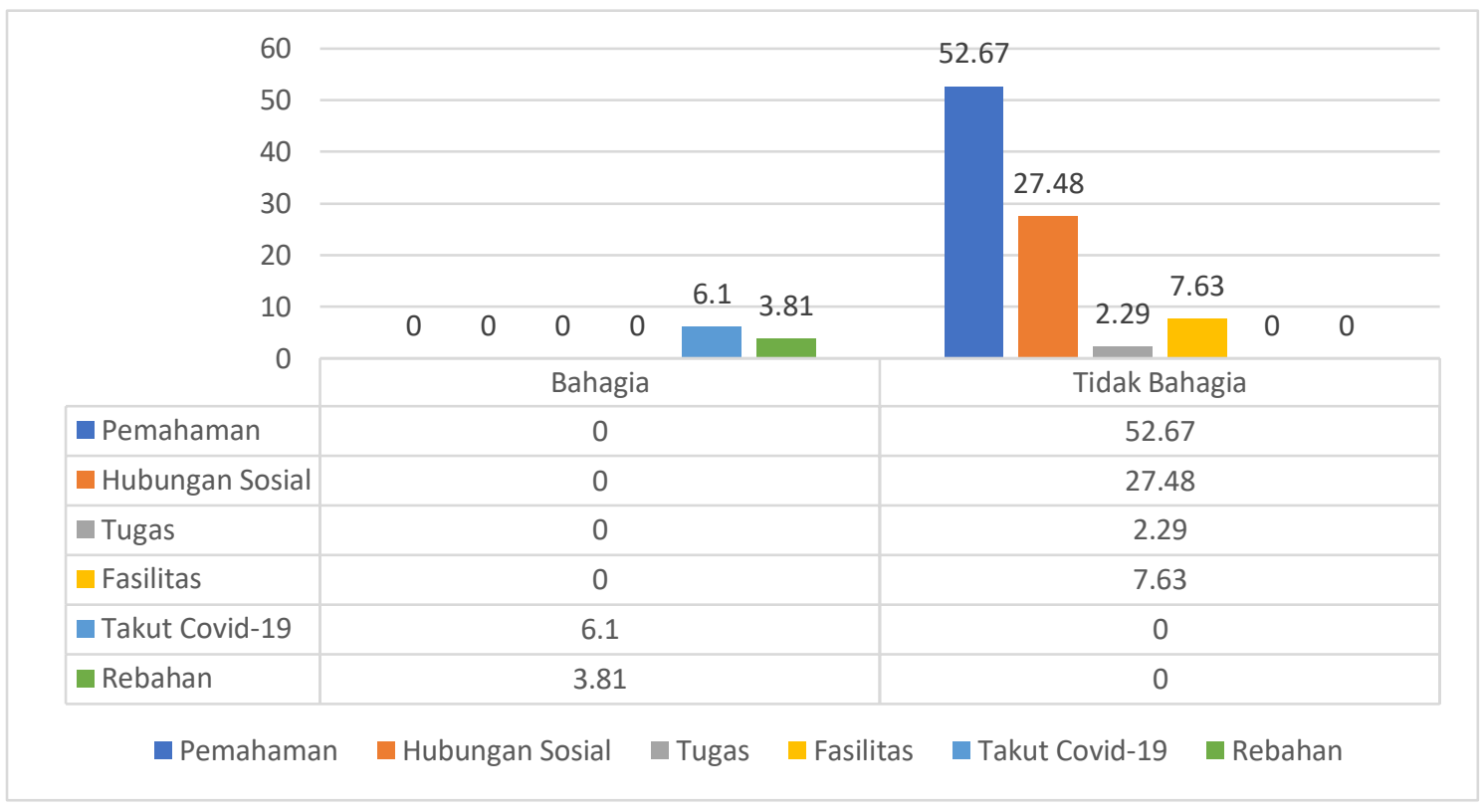

Gambar 7. Gambaran alasan siswa merasa kebahagian

Berdasarkan gambar 6. Diketahui bahwa alasan yang membuat siswa merasa bahagia atau tidak bahagia selama mengikuti pembelajaran daring selama pandemi. siswa merasa tidak bahagia dikarenakan pemahaman dalam materi pembelajar sebanyak $52.67 \%$ siswa, dikarenakan hubungan sosial antara guru dan teman disekolah sebanyak $27.48 \%$ siswa, dikarenakan berkaitan dengan tugas yang diberikan sebanyak $2.29 \%$ siswa, dikarenakan fasilitas selama pembelajaran sebanyak $7.63 \%$ siswa dan siswa yang merasa bahagia selama mengikuti pembelajar daring dikarenakan takut tertular covid-19 sebanyak $6.1 \%$ siswa dan merasa bahagia karena bisa rebahan dirumah sebanyak $3.81 \%$ siswa.

\section{Pembahasan}

Dari hasil penelitian ini diketahui bahwa siswa lebih banyak merasa tidak bahagia selama melaksanakan sistem pembelajaran daring dan terdapat berbagai kendala yang dihadapi siswa selama proses pembelajaran dengan sistem daring dimasa pandemic terkait pemahaman materi karena kurangnya penjelasan dari guru dan fasilitas dalam pelaksanaan pembelajaran sistem daring selama masa pandemi.

Dalam pelaksanaan pembelajaran daring dibutuhkan berbagai perlengkapan tambahan seperti hp atau laptop dan biaya tambahan untuk kuota paket data yang harus dipersiapkan siswa, dalam kajian yang dilakukan (Handarini, 2020) menjelaskan bahwa 
1. Medote daring merupakan solusi untuk melakukan social distancing untuk mencegah mata rantai penyebaran wabah covid 19. Karena pembelajaran daring merupakan pembelajaran yang dilakukan secara onlinedengan jarak jauh atau pembelajaran yang dilakukan peserta didik dimanapun dan kapanpun saat dibutuhkan. Sehingga tidak terjadi perkumpulan yang menjadi salah satu upaya dalam social distancing.

2. Study from home (SFH) adalah metode yang digunakan karena pandemic covid-19, yang merubah proses belajar di sekolah menjadi belajar dirumah. Namun sesuai tanggapan banyak siswa dalam pelaksanaannya, siswa lebih cenderung ingin kembali belajar disekolah.

3. Pembelajarang daring membutuhkan sarana dan prasarana yang dapat mendukung pelaksanaan daring yaitu smartphone, computer, laptop dan terutama jaringan internet. Sarana prasarana ini lah yang menjadi tantangan dalam proses daring.

4. Metode daring mampu membuat siswa menjadi mandiri dalam belajar dikarenaka pembelajaran berpusat pada siswa ataua student centered yang memnuntut siswa untuk lebih aktif dalam menyapaikan pendapatnya.

Terdapat kurang lebih 200 Negara yang ada di Dunia terpapar pandemic covid-19 termasuk Indonesia. Telah berupaya melakukan pencegahan, pengobatan, dan sebagainya dalam mencegah penyebaran pandemo covid-19, bahkan melaksanakan Pembatas seosial berskala besar (PSBB) dan social distancing di kota-kota besar sudah dilakukan untuk memutus rantai penyebaran virus covid-19. Dalam Islam wabah pandemic covid-19 merupakan cobaan bagi ummat untuk senantiasa mengingat Allah SWT. Dalam islam ada kata lockdown dan social distancing yang menjelaskan terkait pencegahan penularan penyakit, sebagian para ulama menggunakan kata Tho'un yaitu wabah yang mengakibatkan penduduk sakit dan berisiko menular (Supriatna, 2020).

Ditengah pendemi covid-19, pembelajaran daring merupakan sebuah sistem pemebelajaran yang efektif dalam menurunkan angka penularan covid-19. Namun dari hasil data yang diperoleh diketahui bahwa siswa kelas VII SMP Negeri 45 Pekanbaru lebih menginginkan pembelajaran tatap muka secara langsung di sekolah karena siswa sebagai makhluk sosial para siswa menginginkan adanya interaksi sosial kepada guru dikelas dan teman-teman sekolah.

Beberapa alasan siswa yang merasa tidak bahagia selama menjalankan kegiatan pembelajaran dengan menggunakan metode pembelajaran daring selama masa pandemic covid-19 yang diungkapkan subjek berkaitan dengan pemahaman siswa terhadap materi pembelajaran, hubungan sosial dengan guru dan teman-teman disekolah, tugas yang diberikan guru, fasilitas yang berkaitan dengan kuota internet, perangkat, jaringan.

"Karna belajar daring tidak menyenangkan dan bikin bosan.kadang jaringan nya gk bagus.dan kekurangan ekonomi membeli paket” S 015

"Saya tidak bahagia karena belum cukup memahami pelajaran yang diberikan olah guru, kemudian saya tidak bisa bertemu dengan teman -teman seperti dulu, Karena 
daring ini jujur saja saya semakin malas untuk belajar dan selalu merasa bosan di rumah." S 022

"Karna belajar daring itu tidak menyenangkan, pelajaran susah di mengerti, tidak ada penjelasan, karna itu saya memilih tidak bahagia. " 033

"Karena belajar secara daring tidak seru..dan tidak ada pelajaran yg masuk,karna kalau di sekolah saya bisa bertanya kepada guru secara langsung..berbeda saat melakukan daring." S 035

“Karena HP hanya 1 dirumah, sedangkan yg belajar ada 3" S 057

“Karena kadang kadang jaringan kurang mendukung” S 071

"Karna saya tidak punya teman dirumah terus dan saya bosan" S094

“Karena, tidak paham pembelajaran yang diberikan secara daring” S 104

"Saat belajar daring dari rumah,saya tidak bahagia.karena belajar secara daring dari rumah banyak sekali kendalanya,mulai dari saat belajar daring kita harus memakai internet dan untuk memakai internet harus membeli kuota, belum lagi jika disekitar rumah kehilangan signal atau jaringan .pada zaman sekarang banyak sekali materimateri pelajaran baru yang datang. Jadi para siswa harus dapat memahami pelajaran tersebut dengan belajar efektif dan dibantu oleh guru.tetapi sekarang,ada sebuah wabah penyakit yaitu virus Corona(covid 19) yang sudah menyebar ke semua daerah.jadi para siswa harus belajar daring dari rumah.belajar daring dari rumah bisa mempersulit siswa untuk memahami pelajaran,karena tiada nya penjelasan dan penerangan tentang pelajaran dari guru.dan jika guru menjelaskan dan menerangkan pelajaran maka itu akan terbatas karena melalui daring." S 110

"Menurut saya pribadi,belajar secara daring kurang menyenangkan karena ilmu yang saya dapat tidak semaksimal seperti belajar secara tatap muka dan yang paling tidak menyenangkan dengan belajar daring adalah menghilangnya sosialisasi dengan guru dan teman-teman semua" S 113

"Jawaban saya tidak bahagia karna pada saat pembelajaran daring saya merasa bosan dan pusing saat belajar sendiri dirumah yg biasanya disekolah belajar bersama dg teman $\hat{A}^{2}$ dan banyak pelajaran yg tidak dimengerti jika hanya belajar sendiri, penjelasan yg diberikan guru pun minim, dan hal ini yg membuat saya pun jarang mengerjakan tugas $\hat{A}^{2}$ yg diberikan guru dan mengirimkan tugasnya pun kadang telat, jadi hal ini yg membuat saya tidak bahagia pada saat pembelajaran daring selama covid-19” S 114 
Psikobuletin: Buletin Ilmiah Psikologi

Vol. 2, No. 2, Mei, 2021 (91-103)

$e-I S S N$ : $2720-8958$

DOI : 10.24014/pib.v2i2.12326

Dan beberapa alasan siswa yang merasa tetap bahagia mengikuti proses pembelajaran selama masa pandemi meskipun dengan metode daring hal ini dikarenakan siswa merasa metode daring merupakan metode yang terpat untuk terhindari dari penularan covid-19 bahkan merasa bahagia dengan mengikuti daring karena bisa rebahan atau menghabiskan waktu santai selama dirumah.

“Karena takut tertular covid-19” S 068

"Karena ini salah satu jalan yang terbaik dimasa pandeni seperti ini supaya tidak banyak orang yang terkena Virus Covid 19 di kawasan sekolah" S 091

"Lebih nyaman daring dirumah,gk perlu kemana mana,lebih sering rebahan dirumah" S065

“krna bs bangun siang” S 023

Dalam kondisi yang dihadapi oleh siswa dalam sistem pembelajaran daring selama masa pandemi, hal ini merupakan peranan penting guru BK untuk dapat mengidentifikasi dan melaksanakan konseling kepada siswa yang mengalami kendala dan hambatan selama proses pembelajaran secara daring agara siswa tetap dapat mengikuti pembelajaran secara baik. Dalam pelaksanaan konseling selama masa pandemi dapat dilaksanakan dengan E-Konseling atau home visit dengan tetap mengikuti protocol kesehatan covid-19 (Putra \& Shofaria, 2020; Putri, 2020 ).

Pelaksanaan kegiatan konseling bukan hanya dilaksanakan face to face, tetapi juga bisa dilaksanakan secara online dengan metode konseling oneline atau E-Konseling (Ifdil \& Ardi, 2013). Dalam kondisi pandemi covid-19 saat ini, konseling online merupakan metode yang tepat untuk digunakan untuk tetap terhubung dengan siswa dengan menggunakan hardwar dan sofewar dengan bantuan media website (content management system), telepon atau hand phone, email, chat (whatsapp, facebook, instagram, skype, messenger, google talk), dan video conference (zoom, google meet, webex, teams). Hal ini juga memiliki keterbatas yang sangat tergantung dengan dukungan media yang digunakan dan gangguan jaringan, listrik mati atau kemampuan user dalam menggunakan media. Namun, Metode konseling online ini cukup efektif untuk menyelesaikan permasalahan yang dihadapi siswa yang membutuhkan penyelesaian segera untuk dituntaskan selama masa pandemi.

Metode konseling yang dapat digunakan dalam meningkatkan kebahagiaan siswa bisa menggunakan metode snowball throwing metode konseling kelompok. Metode pembelajaran melempar bola salju dapat diterapkan sebagai salah satu konseling kelompok yang inovatif metode yang akan dilakukan dalam dunia pendidikan, karena Penggunaan media membuat siswa tidak bosan saat konseling berkelompok. Pelaksanaan kelompok konseling melalui metode melempar bola salju bisa menjadi salah satunya 
alternatif inovatif dalam pelaksanaan kelompok konseling yang biasanya bersifat konvensional, ini sejalan dengan peningkatan kebahagiaan yang dirasakan oleh siswa yang merupakan subjek penelitian. Jadi bisa disimpulkan bahwa kebahagiaan bisa ditingkatkan melalui konseling kelompok yang berisi diskusi, salah satunya dengan mencoba metode pembelajaran melempar bola salju dalam implementasinya (Bahiroh et al., 2020).

\section{Kesimpulan dan Saran}

Dapat disimpilkan bahwa siswa merasa tidak bahagia dan mengalami kendala dalam pembelajaran daring selama masa pandemic. Kendala yang dihadapi adalah dalam memahami materi selama proses pembelajaran daring di masa pandemi. Sebagian besar siswa mengingikan sistem pembelajaran secara tatap muka secara langsung di sekolah karena sebagai mahluk sosial, siswa menyukai interaksi sosial kepada guru dan temanteman di sekolah. Alasanan yang membuat siswa merasa tidak bahagia selama daring adalah karena sulit dalam memhami materi, hubugan sosial yang berkurang dengan guru dan teman-teman sekolah, tugas yang diberikan dan fasilitas yang kurang mendukung selama daring Sehingga dapat dikatakan bahwa siswa akan lebih bahagia ketika belajar di sekolah dari pada pembelajaran daring karena siswa akan mampu memenuhi dimensidimensi kebahagiaan dalam menjalin relasi positif dengan individu lain, penguasaan lingkungan, pertumbuhan pribadi, otonomi, penerimaan diri dan penetapan tujuan hidup.

Penulis menyarankan untuk tetap melaksanakan pelayanan konseling kepada siswa dengan metode layanan konseling online selama masa pandemi covid-19 dan metode konseling kelompok lempar salju untuk meningkatkan kebahagiaan siswa.

\section{Referensi}

Bahiroh, S., Pratiwi, S. A., \& Suud, F. M. (2020). Improving student happiness through the snowball throwing method in the implementation of student conceling groups of state vocational schools 2 Depok yogyakarta. Journal of Critical Reviews, 7(5), 563-568. https://doi.org/10.31838/jcr.07.05.117

Diah, H., Hadi, D. R., Isbaniah, F., Burhan, E., \& Heidy Agustin. (2020). Penyakit Virus Corona 2019. 40(2), 119.

Diener, E. (2000). Subjective well-being: The science of happiness and a proposal for a national index. American Psychologist, 55(1), 34-43. https://doi.org/10.1037/0003-066X.55.1.34

Diener, E., Suh, E. M., Lucas, R. E., \& Smith, H. L. (1999). Subjective well-being: Three decades of progress. Psychological Bulletin, 125(2), 276-302. https://doi.org/10.1037/0033-2909.125.2.276 
Galuh, S. A., \& Utami, M. S. (2009). Religiusitas dan Psychologycal Well Being pada Korban Gempa. Jurnal Psikologi, 34(2), 164-176. https://doi.org/10.1007/978-3540-85867-6_16

Handarini, O. I. (2020). Pembelajaran Daring sebagai Upaya Study From Home (SFH) selama Pandemi Covid 19. Jurnal Pendidikan Administrasi Perkantoran (JPAP), 8(3), 639-643. https://doi.org/10.1093/fampra/cmy005

Ifdil, I., \& Ardi, Z. (2013). Konseling Online Sebagai Salah Satu Bentuk Pelayanan Ekonseling. Jurnal Konseling Dan Pendidikan, 1(1), 15-21. https://doi.org/10.29210/1400

Isbaniah, F., \& Susanto, A. D. (2020). Pneumonia Corona Virus Infection Disease-19 ( COVID-19 ). Pneumonia Corona Virus Infection DIsease-19 (COVID-19), 70(4), 87-94.

Kim, U., Yang, K.-S., \& Hwang, K. (2006). Paternalism. In Indigenous and Cultural Psychology Understanding people in context. https://doi.org/10.4324/9780203124352

Muhammad, R., Saefulmilah, I., \& Saway, M. H. M. (2020). Jurnal Pendidikan dan Ilmu Sosial. HAMBATAN-HAMBATAN PADA PELAKSANAAN PEMBELAJARAN DARING DI SMA RIYADHUL JANNAH JALANCAGAK SUBANG Rd., 2(November), 393-404. https://ejournal.stitpn.ac.id/index.php/nusantara

Putra, M. A., \& Shofaria, N. (2020). Inovasi Layanan Bimbingan Dan Konseling Di Masa Pembelajaran Dalam Jaringan Masa Pandemi Covid-19. Bikotetik (Bimbingan Dan Konseling: Teori Dan Praktik), 4(2), 55. https://doi.org/10.26740/bikotetik.v4n2.p55-61

Ryff, C. D. (1989). Happiness is everything, or is it? Explorations on the meaning of psychological well-being. Journal of Personality and Social Psychology, 57(6), 1069-1081. https://doi.org/10.1037/0022-3514.57.6.1069

Ryff, C. D., \& Keyes, C. L. M. (1995). The Structure of Psyvhological Well-Being Revisited. Journal of Personality and Social Psychology, 69(4), 719-727.

Supriatna, E. (2020). Wabah Corona Virus Disease (Covid 19) Dalam Pandangan Islam. SALAM: Jurnal Sosial Dan Budaya Syar-I, 7(6). https://doi.org/10.15408/sjsbs.v7i6.15247

Yuliana. (2020). Corona Virus diasease (Covid-19); Sebuah tinjauan literatur. Wellnes and Healthy Magazine, 2(February), 187-192. https://doi.org/10.2307/j.ctvzxxb18.12 